\title{
EVALUATION OF RADIATION DOSE RATE OF RSG-GAS REACTOR
}

\author{
Amir Hamzah, Hery Adrial, Subiharto \\ Center for Reactor Technology and Nuclear Safety - BATAN \\ National Nuclear Energy Agency of Indonesia \\ Kawasan Puspiptek Serpong Gd.80, Tangerang Selatan, Banten 15314 \\ e-mail: ahamzah@batan.go.id
}

(Naskah diterima: 01-11-2018, Naskah direvisi: 04-12-2018, Naskah disetujui: 12-12-2018)

\begin{abstract}
EVALUATION OF RADIATION DOSE RATE OF RSG-GAS REACTOR. The RSG-GAS reactor has been operated for 30 years. Since the nuclear reactor has been operated for a long time, aging process on its components may occur. One important parameter for maintaining the safety level of the RSG-GAS reactor is to maintain radiation exposure as low as possible, especially in the working area. The evaluation results should be able to demonstrate that the radiation exposure of the RSG-GAS is still safe for workers, communities and the surrounding environments. The purpose of this study is to evaluate radiation exposure in the working area to ensure that the operation of RSG-GAS is still safe for the next 10 years. The scope of this work is confirming the calculation results with the measured radiation dose in the RSG-GAS reactor working area. Measurement of radiation exposure is done by using the installed equipments at some points in the RSG-GAS working area and a portable radiation exposure measurement equipment. The calculations include performance of a modeling and analysis of dose rate distribution based on the composition and geometry data of RSG-GAS by using MCNP. The analysis results show that the maximum dose rate at Level $0 \mathrm{~m}$ working area of RSG-GAS reactor is $3.0 \mu \mathrm{Sv} / \mathrm{h}$ with a deviation of $6 \%$, which is relatively close to the measurement value. The evaluation results show that the dose rate in RSG-GAS working area is below the limit value established by the Nuclear Energy Regulatory Agency of Indonesia (BAPETEN) of $10 \mu \mathrm{Sv} / \mathrm{h}$ (for the average effective dose of $20 \mathrm{mSv} /$ year). Therefore, it is concluded that the dose rate in RSG-GAS working area is safe for personnel..
\end{abstract}

Kata kunci: dose rates, RSG-GAS, radiation safety, MCNP. 


\section{ABSTRAK}

EVALUASI LAJU DOSIS RADIASI REAKTOR RSG-GAS. Reaktor RSG-GAS telah beroperasi selama 30 tahun. Operasi reaktor yang lama dapat memungkinkan terjadinya proses penuaan pada komponennya. Salah satu parameter penting untuk menjaga tingkat keselamatan reaktor RSG-GAS adalah paparan radiasi yang serendah mungkin, terutama di daerah kerja. Hasil evaluasi harus dapat menunjukkan bahwa paparan radiasi RSG-GAS masih aman bagi pekerja, masyarakat dan lingkungan sekitar. Tujuan penelitian ini adalah untuk mengevaluasi paparan radiasi di daerah kerja untuk memastikan bahwa operasi RSG-GAS masih aman untuk 10 tahun ke depan. Ruang lingkup pekerjaan ini adalah untuk memvalidasi hasil perhitungan dibandingkan dengan pengukuran dosis radiasi di daerah kerja reaktor RSG-GAS. Pengukuran paparan radiasi dilakukan dengan menggunakan peralatan yang terpasang di beberapa titik di area kerja RSG-GAS dan peralatan pengukuran paparan radiasi portabel. Perhitungan yang dilakukan adalah pemodelan dan analisis distribusi laju dosis berdasarkan data komposisi dan geometri RSG-GAS menggunakan MCNP. Hasil analisis laju dosis maksimum pada area kerja Level $0 \mathrm{~m}$ reaktor RSG-GAS adalah 3,0 $\mu$ Sv/jam dengan penyimpangan $6 \%$ yang relatif mendekati hasil pengukuran. Hasil evaluasi menunjukkan bahwa tingkat dosis di wilayah kerja RSG-GAS masih di bawah batas nilai $10 \mu \mathrm{Sv} / \mathrm{jam}$ (untuk dosis efektif rerata $20 \mathrm{mSv} / \mathrm{tahun}$ ) yang ditentukan oleh BAPETEN sehingga aman untuk pekerja.

Kata kunci: laju dosis, RSG-GAS, keselamatan radiasi, MCNP. 


\section{INTRODUCTION}

The RSG-GAS reactor was inaugurated in 1987 and it has been operated more than 20 years. The operator has been controlling within acceptable limits the ageing degradation and wear-out of plant components important to safety so that adequate safety margins remain. The ageing on the component may lead the increasing radiation exposure in the working area and environment. One important parameter to maintain the safety and security level of the nuclear reactor is the evaluation of radiation exposure in the working area and the surrounding environment. Evaluation of RSG-GAS radiation exposure during the last 10 years were conducted in order to see any changes in radiation safety levels at working area due to ageing process undergo in the components. The purpose of this study is to evaluate radiation exposure in the working area to ensure that the operation of RSG-GAS is still safe at least for the next 10 years. The scope of this evaluation is the measurement and calculation of radiation exposure in the RSG-GAS reactor working area.

The dose rate calculations with the simple RSG-GAS reactor modelhave been studied but there is no applied validation or verification yet[1]. That study only showed that the dose rate calculation is done at some points just above the surface of the RSG-GAS reactor pool. Therefore this paper aims to present the results of the radiation dose rates distribution analysis in RSG-GAS working areas that have been confirmed with measurement results. This radiation dose rates distribution includes almost all working areas of Level $0 \mathrm{~m}$, Level $8 \mathrm{~m}$, Level $13 \mathrm{~m}$, and Level $-6 \mathrm{~m}$.

Measurements of radiation exposure were done using equipments attached at some points in the RSG-GAS working area and portable radiation exposure measurement equipments. Calculation of the dose rate distribution is done using the MCNP program[2]. The Monte-Carlo technique of the MCNP program has been widely used to solve of various nuclear reactor problems, especially in complex geometry modeling[3,5]. The analysis of the dose rate distribution started from the modeling of the core, radiation shielding up to the reactor building according to the composition and geometry of each component. The modeling was done using VisEd which is part of MCNP pakage. Based on the model that has been made, then the distribution of dose rate in several working areas inside the reactor building and outside the reactor building have been analyzed. Thus it can be determined identification room based on radiation exposure so that the principle of ALARA (As Low As Reasonably Achievable) can be applied effectively and efficiently to ensure radiation safety, especially for workers. The expected results of this study are the distribution of safe radiation dose rates for workers and communities including environments that meet BAPETEN requirements with a dose limit value (DLV) of $20 \mathrm{mSv} / \mathrm{year}$ (20 millisieverts/year) and $1 \mathrm{mSv} /$ year (1 millisievert/year) respectively[6].

\section{THEORY}

The MCNP code has been widely used to calculate the particle flux based on Monte-Carlo method. In the Monte-Carlo method, the particle count passing through a given location is scored, the count of the particle is the flux at that observed location. However, the output of MCNP is in normalized flux value, so it takes a value as a normalization factor to get the absolute particle flux value. The magnitude of the normalization factor is obtained from the equation $1[7,8]$.

$$
F M=\left(\frac{1 \text { joule } / \text { detik }}{\text { watt }}\right)\left(\frac{1 \mathrm{MeV}}{1,602 \times 10^{-13} \text { joule }}\right)\left(\frac{\text { fisi }}{180 \mathrm{MeV}}\right) \times P \times \eta / k_{\text {eff }}
$$


with:

$P=$ reactor power $=3 \times 10^{7} \mathrm{~W}$ (30 MW power of RSG-GAS),

$\eta=$ the number of neutrons produced per fission reaction (MCNP output),

$k_{\text {eff }}=$ neutron effective mulitiplication factor (MCNP output).

This multiplication factor (FM) is used as a normalization/multiplier factor to the particles counting results in a given position (tally) of the MCNP to obtain the neutron and gamma flux. The dose rate is determined by multiplying the flux-to-dose conversion factor to that particle flux.

\section{METHODOLOGY}

The fuel elements (FE) and control elements (CE) of RSG-GAS reactor core are plate type consists of 21 and 15 fuel element plates (FEP) with $2.96 \mathrm{gU} / \mathrm{cm}^{3}$ density of $\mathrm{U}_{3} \mathrm{Si}_{2} / \mathrm{Al}$ meat repectively. The RSG-GAS reactor core consists of $40 \mathrm{FE}$ and $8 \mathrm{CE}$ including 4 irradiation position (IP) and central irradiation position (CIP) [9. The core composition and all other reactor components are calculated in weight percent based on the RSG-GAS reactor core data. The composition of main components of RSG-GAS reactor was tabulated in Table 1. The composition of other related material data is taken from a reliable source [10].

Table 1. Composition of all RSG-GAS reactor components in w/o and density in $\mathrm{gU} / \mathrm{cm}^{3}[9,10]$.

\begin{tabular}{|c|c|c|c|c|c|c|c|c|}
\hline No. Ident. & $\begin{array}{l}\text { FE } 250 \\
\text { Silicide }\end{array}$ & $\begin{array}{l}\text { CE } 250 \\
\text { Silicide }\end{array}$ & AIMg-2 & AlMgSi-1 & Water & $\begin{array}{l}\text { Ordinary } \\
\text { Concrete }\end{array}$ & $\begin{array}{l}\text { Heavy } \\
\text { Concrete }\end{array}$ & Air \\
\hline $1001.80 c$ & 0.034300 & 0.034428 & - & - & 0.111894 & 0.010 & 0.003585 & - \\
\hline $6000.80 c$ & - & - & - & - & - & - & - & 0.000124 \\
\hline $7014.80 \mathrm{c}$ & - & - & - & - & - & - & - & 0.755268 \\
\hline $8016.80 c$ & 0.272222 & 0.273231 & - & - & 0.888106 & 0.532 & 0.311622 & 0.231781 \\
\hline $11023.80 c$ & - & - & - & - & - & 0.029 & - & - \\
\hline $12000.62 c$ & 0.006638 & 0.006627 & 0.0205 & 0.00900 & - & - & 0.001195 & - \\
\hline $13027.80 \mathrm{c}$ & 0.488379 & 0.487758 & 0.9630 & 0.95725 & - & 0.034 & 0.004183 & - \\
\hline $14000.60 c$ & 0.015973 & 0.015938 & 0.0030 & 0.01025 & - & 0.337 & 0.010457 & - \\
\hline $16000.62 c$ & - & - & - & - & - & - & 0.107858 & - \\
\hline $18000.42 c$ & - & - & - & - & - & - & - & 0.012827 \\
\hline $20000.62 c$ & - & - & - & - & - & 0.044 & 0.050194 & - \\
\hline $22000.62 c$ & 0.000389 & 0.000389 & 0.0010 & 0.00100 & - & - & - & - \\
\hline $24000.50 c$ & 0.000993 & 0.000991 & 0.0030 & 0.00150 & - & - & - & - \\
\hline $25055.80 c$ & 0.001631 & 0.001632 & 0.0030 & 0.00700 & - & - & - & - \\
\hline $26000.55 c$ & 0.001672 & 0.001671 & 0.0040 & 0.00500 & - & 0.014 & 0.047505 & - \\
\hline $28000.50 d$ & - & - & - & - & - & - & - & - \\
\hline $29000.50 c$ & - & - & - & - & - & - & - & - \\
\hline $30000.70 c$ & 0.000778 & 0.000777 & 0.0020 & 0.00200 & - & - & - & - \\
\hline $56138.80 c$ & - & - & - & - & - & - & 0.463400 & - \\
\hline $92235.80 c$ & 0.034775 & 0.034682 & - & - & - & - & - & - \\
\hline $92238.80 \mathrm{c}$ & 0.141300 & 0.140924 & - & - & - & - & - & - \\
\hline Density: & 1.955885 & 1.952611 & 2.68 & 2.7 & 0.998207 & 2.3 & 3.35 & 0.001205 \\
\hline
\end{tabular}


As can be seen in Table 1, the difference between heavy concrete and ordinary one generally lies in the content of oxygen, silicon, iron, and barium. Ordinary concrete contains more oxygen and silicon while heavy concrete contains more iron and barium. Compared to oxygen and silicon, the iron and barium elements have greater neutron cross-section [11-13] and higher density, thus their ability as a radiation shielding is much better. But heavy concrete is more expensive, so it is necessary to determine the optimal combination of shielding substances and dimensions.

The design of the radiation shielding shall meet the radiation safety criteria to ensure the safety of workers and the surrounding community. This was done both during the design stage and certainly in practice during the operation of the nuclear reactor. The provisions are contained in the BAPETEN Head Regulation No. 4 of 2013 on Protection and Radiation Safety in the Utilization of Nuclear Power [6]. The effective dose limit value (DLV) must be met in all stages starting from designing, operating and decommissioning on all nuclear installations to ensure radiation safety for workers and surrounding communities.

Calculation of radiation dose rates based on the RSG-GAS reactor model has been done using MCNP with a cross-section library compiled from ENDF/B-VII for neutrons, protons and photo-nuclear interactions for up to $100 \mathrm{MeV}$ [14-16]. The accuracy of the calculation results in the MCNP program is at least determined by 3 parameters i.e. the relative error with the standard deviation $\mathrm{R}$ less than 0.05 , the variance of variance (VOV) less than 0.1 , and the figure of merit (FOM) is constant [2].

In the defining the source of radiation, it requires a strong value of the radiation source (source strength). The core neutron source strength was calculated by equation (1) whereas the gamma sources strength of radiative capture and spontaneous fission were calculated analytically and radioactive decay was calculated using ORIGEN2.1 [17-19]. The source strength calculation of the core decay was carried out in accordance with the reactor power and its cycle length and calculated under the maximum burn-up condition of about $56 \%$. Those values are then used as a multiplication/normalization factor to the tally value of the MCNP output in accordance with the reactor conditions.

The validation procedure was done to see how accurate the simulation results. Due to the measurements of radiation exposure in RSG-GAS reactor working areas did not the exact same condition with calculation ones, so the measurements are used just to confirm the calculation results.

\section{RESULTS AND DISCUSSION}

\section{a. Reactor model}

The result of core modeling and arrangement of radiation shielding and neutron beam tubes of RSG-GAS reactor can be seen in Figure 1 and 2. As seen in that figures, radially, from the core to the outside of the reactor building, the radiation shielding materials and thickness of the RSG-GAS reactor are tabulated in Table 2 with a total of up to 9 layers of various types and sizes of shielding. During simulation, all ractor components are modeled in cylindrical geometry, so the radial shielding layers are represented in equivalent radious in Table 2. Since this reactor is an open pool reactor, the radiation shielding towards the axial above the core consists of water that also serves as a coolant as tabulated in Table 3 . In this calculation, the core composition in Tabel 2 and 3 is a mixture of all materials of $40 \mathrm{FE}, 8 \mathrm{CE}$ and $4 \mathrm{IP}$. The water colomn in CIP was in the middle of core.

The reactor core model and the radiation shielding arrangement and neutron tubes of the RSG-GAS reactor radially and axially can be seen in Figure 1 and 2 . Reactor core towards the radial direction is surrounded by cooling water, reactor tank, 
heavy concrete and ordinary concrete, the airspace of Experimental Hall and reactor building. The shielding materials and thickness of each layer are listed in Table 2 and 3 . In this model, the core center is used as a central point $(0,0,0)$ of all systems. On that basis, the RSG-GAS reactor active core is between $z=-30 \mathrm{~cm}$ and $z=30 \mathrm{~cm}$. All systems follow these coordinates and Figure 1 (a) is at $z=-10 \mathrm{~cm}$ level while Figure 1 (b) is at $z=10 \mathrm{~cm}$. Thus, the S1, S3, and S5 neutron beam tubes are different levels with the S2, S4, and S6. But all the neutron beam tube centers are at the same point at the core midplane that axially known having higher neutron flux than at the top or bottom of the reactor core. That's why the beam tubes are made to exploit the neutron beam that goes through it for a variety of studies that are neutron scattering research, neutron radiography, and others.

Table 2. Radial shielding layers of RSG-GAS reactor[9].

\begin{tabular}{clr}
\hline Region number & \multicolumn{1}{c}{ Materials } & Thickness (cm) \\
\hline & Central Irradiation Position (CIP; r equivalent) & 8.92 \\
1 & Reactor core (r equivalent) & 24.44 \\
2 & Al-alloy (core shroud) & 1.00 \\
3 & Berilum $\mathrm{H}_{2} \mathrm{O}$ (neutron reflector) & 32.10 \\
4 & Water (reactor pool) & 217.90 \\
5 & Al-alloy (reactor tank) & 2.00 \\
6 & Ordinary concrete (biological shielding) & 60.00 \\
7 & Heavy concrete (biological shielding) & 139.00 \\
8 & Air (Eksperiment Hall) & 2000.00 \\
9 & Ordinary concrete (reactor wall) & 50.00 \\
& Air (outside of reactor building) & 50.00 \\
\hline
\end{tabular}

Table 3. Axial shielding layers of RSG-GAS reactor[9].

\begin{tabular}{clc}
\hline Region number & \multicolumn{1}{c}{ Materials } & Thickness $\mathbf{( c m )}$ \\
\hline 0 & Reactor core & 30 \\
1 & Water (reactor pool) & 1170 \\
2 & Air (Operation Hall) & 100 \\
\hline
\end{tabular}

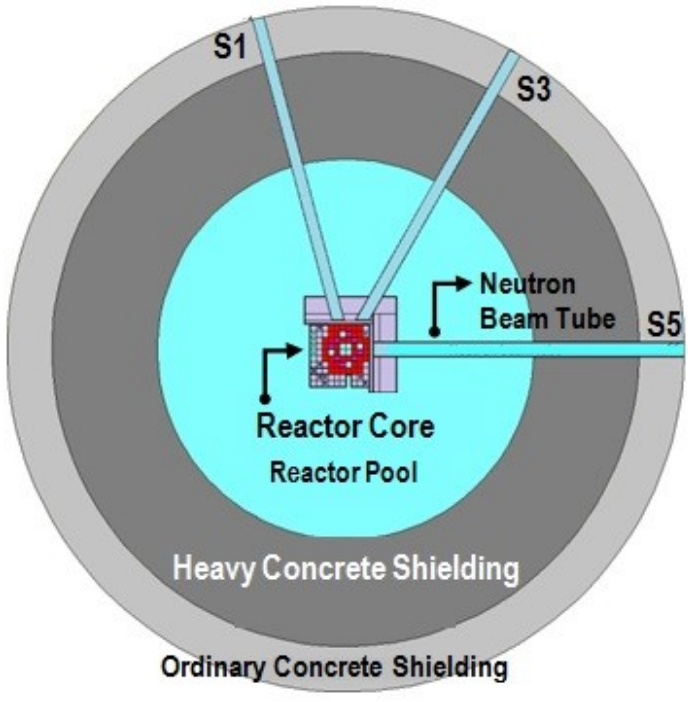

(a). $Z=-10 \mathrm{~cm}$

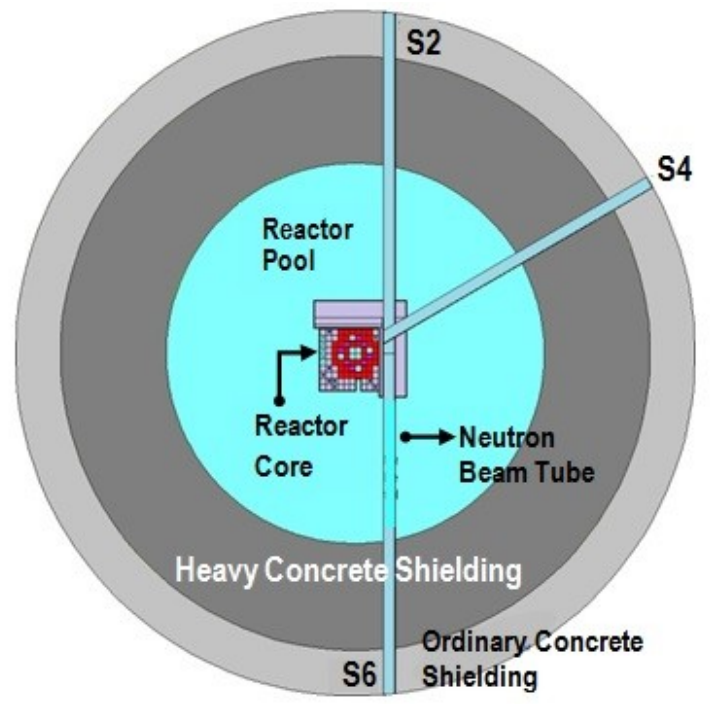

(b) $Z=+10 \mathrm{~cm}$

Figure. 1. Transversal core model with neutron beam tube and shielding of RSG-GAS reactor. 


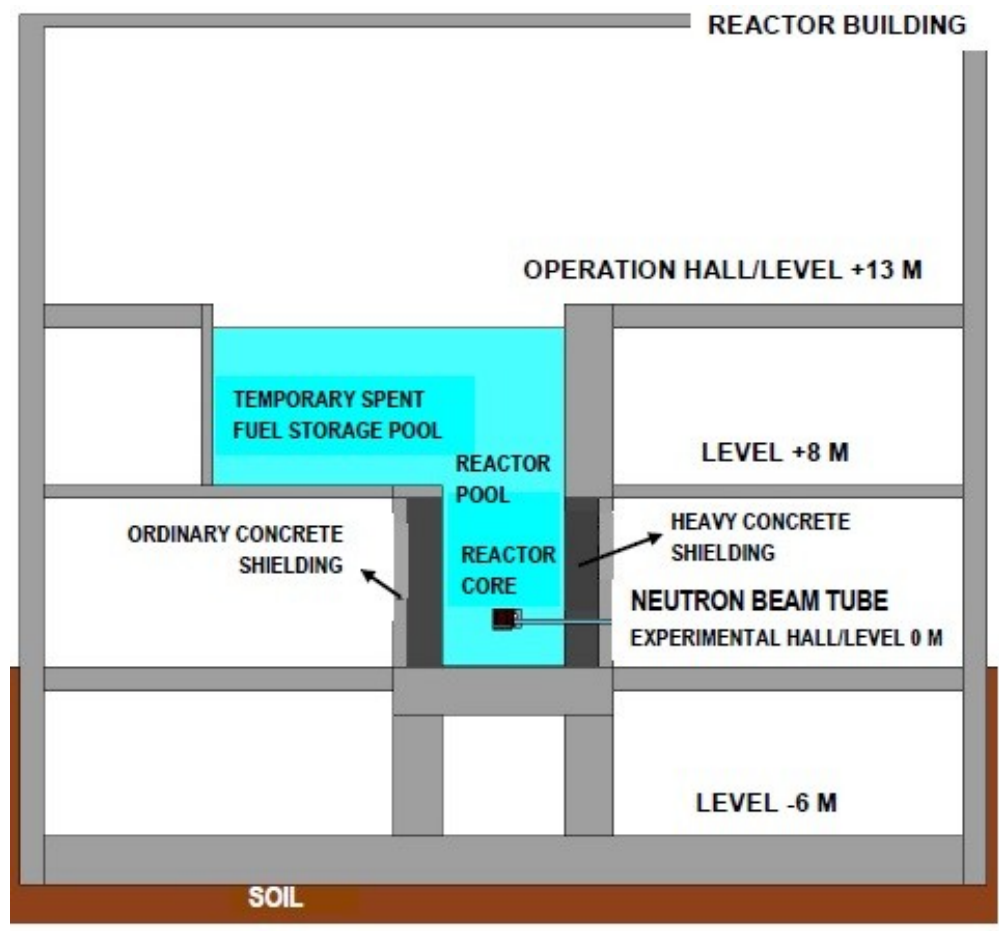

Figure. 2. Longitudinal model of RSG-GAS reactor.

\section{b. Dose rate distribution}

Measurements of radiation exposure were done using equipments attached at some points in the RSG-GAS working area and portable radiation exposure measurement equipments. The radiation exposure measurements at the Level $-6 \mathrm{~m}$, $0 \mathrm{~m}$, Level $8 \mathrm{~m}$ and Level $13 \mathrm{~m}$ during the year of 2005 to 2015 are plotted in Figure 3, 4,5 and 6 respectively[20]. The radiation exposure in the working area, under operating conditions year by year, in general indicates a value less than the dose rates limit value $(10 \mu \mathrm{Sv} / \mathrm{h})$. Some points in Figure 4 and 5 little bit (less than 10\%) exceed the dose rates limit value. The ALARA principle has been being applied during all RSG-GAS reactor activities so the maximum accepted personnel dose is reported to be well below DLV (20 mSv/year)[20].

Figure 4 and 5 show that the radiation exposure measurements in the Experimental Hall at Level $0 \mathrm{~m}$ and Level $8 \mathrm{~m}$ that some points little bit (less than 10\%) exceed the dose rates limit value. This is due to the fact that many experimental facilities or equipments (as additional radiation source) was placed in the Experimental Hall that allows the additional radiation. And in level $8 \mathrm{~m}$ close to the primary cooling pipe that emit gamma radiation during reactor operation.

The radial distribution of dose rates calculation results at Level $0 \mathrm{~m}$, Level $8 \mathrm{~m}$, and Level $-6 \mathrm{~m}$ of RSG-GAS reactor are plotted in Figure 7 while at Level 13 in Figure 8. Figure 7 shows that the radial distribution of the dose rate in the Experimental Hall/Level $0 \mathrm{~m}$ outside the biological shield wall following the negative power function $\left(\mathrm{Cx}^{-2.26}\right)$. The results of the analysis of the maximum dose rate at Level $0 \mathrm{~m}$ working area of RSG-GAS reactor is $3.0 \mu \mathrm{Sv} / \mathrm{h}$ with a deviation of $6 \%$. This is an ideal condition because the calculation was done on the midplane of the core towards the radial direction. The assumption in this analysis is that all neutron beam tubes are closed. And the dose rate calculation results in the working area are relatively close to the measurement results and both of them are still below the DLV so it is safe for personnel. 


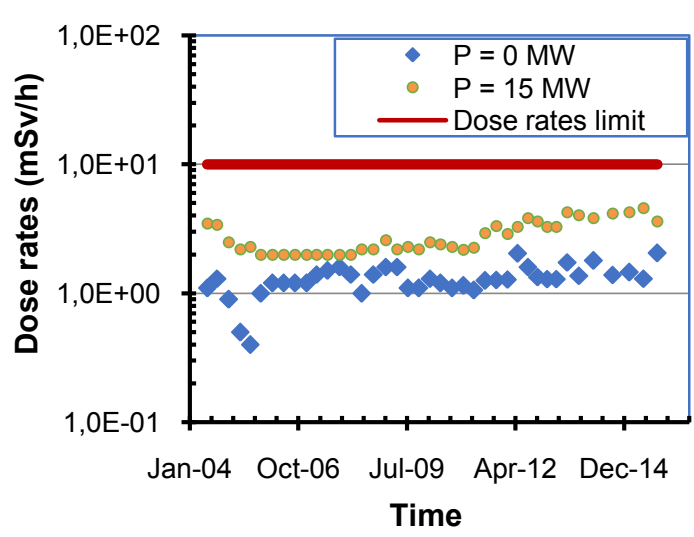

Figure. 3. Radiation dose measured in level $-6 \mathrm{~m}$ of RSG-GAS [20].

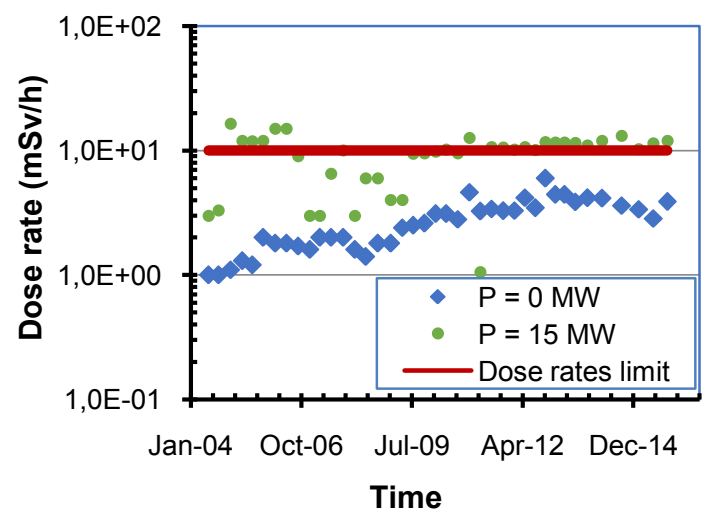

Figure 5. Radiation dose measured in level $8 \mathrm{~m}$ of RSG-GAS [20].

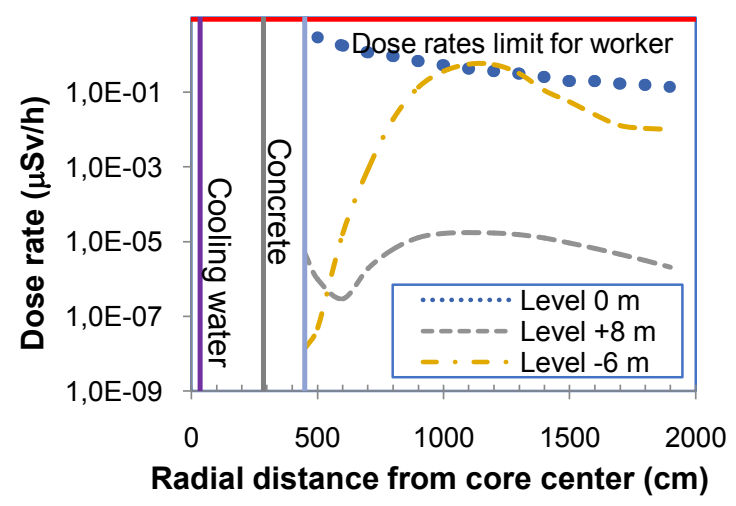

Figure 7. Dose rate distribution at Level $0 \mathrm{~m}$, $8 \mathrm{~m}$, and $-6 \mathrm{~m}$ of RSG-GAS reactor.

The calculation result of the radial distribution of the dose rate at the level $8 \mathrm{~m}$ and $-6 \mathrm{~m}$ are also plotted in Figure 7. It can be seen in Figure 7 that the dose rates at those area are decreases and increases and decreases and formed as the wave along the radial direction. It can be understood that

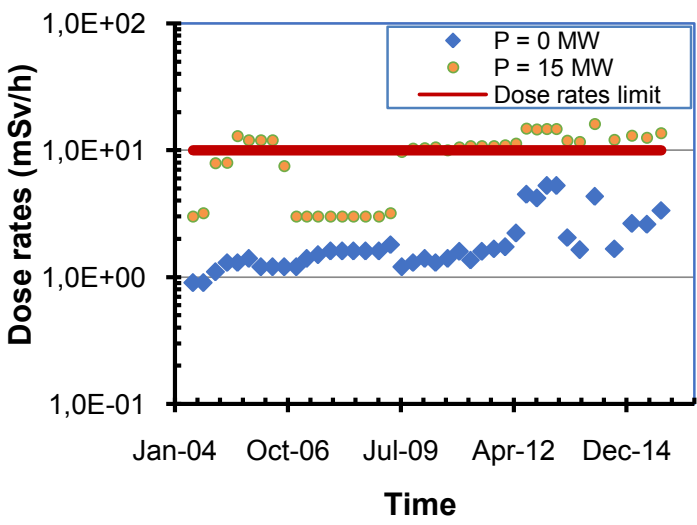

Figure 4. Radiation dose measured in level $0 \mathrm{~m}$ of RSG-GAS [20].

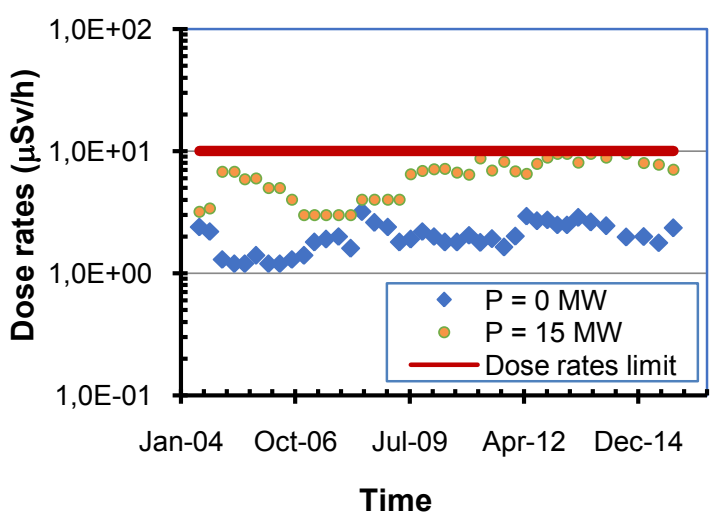

Figure 6. Radiation dose measured in level 13 m of RSG-GAS [20].

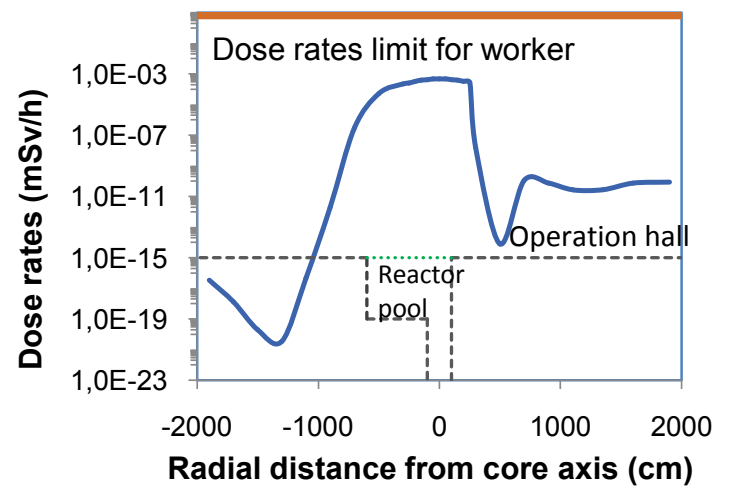

Figure 8. Dose rate distribution in Level 13 m RSG-GAS.

those level 8 and $-6 \mathrm{~m}$ working areas, the dose rate determination are depending on the shielding materials, and thickness and distance of measurement or calculation points. However, the radiation dose rates are far below the DLV so it is safe for personnel. 
The calculation result of dose rate at Level $13 \mathrm{~m}$ is plotted in Figure 8 . It is seen in Figure 8 that the dose rates distribution on $100 \mathrm{~cm}$ above the reactor pool surface is higher than on the Operation Hall floor but it is still below the DLV. The dose rate curve on the right part decreases sharply, as radiation emissions are blocked by the reactor pool walls concrete. However, radiation exposure in the Operations Hall is very low and far below the DLV so it is safe for workers

In general, the results of the calculations are lower than the measurement results, although the calculation is carried out at $30 \mathrm{MW}$. That's because the calculation of the dose rate only takes into account the source of radiation coming from the reactor core. And this Monte-Carlo analysis was done in a static condition, while the reactor coolant water carrying radioactive substances circulates within the reactor pool. Besides that, there are some radioactive materials on the Level $13 \mathrm{~m}$, Level $8 \mathrm{~m}$, and Level $-6 \mathrm{~m}$ in the form of used equipment being treated or some experimental temporary waste before being sent to a radioactive waste treatment plant. The calculation results are somewhat close to the measurement especially at the Level -6 $\mathrm{m}$ with calculation/measurement (C/M) are arround 0.6. This difference arises due to in the analysis it is assumed that all of the core materials and the existing components and including radiation shielding are considered all new and inactive. In fact, all of those RSG-GAS reactor components have been exposed to neutron radiation in during its lifetime. Nevertheless, this calculation could illustrate that the results of radiation exposure analysis in the RSG-GAS reactor working area is not so far from the measurement result.

The calculation results of the rates of radiation dose in the RSG-GAS working area are below the DLV determined in the BAPETEN Head regulation no. 4 year of 2013. Those results are supported by the measurement of radiation exposure conducted by PRSG radiation protection officer. Thus radiation exposure in the RSG-GAS reactor working area is safe for personnel.

\section{CONCLUSION}

The results of dose rate analysis in the RSG-GAS reactor working area have been relatively confirmed with the measurement results. In terms of radiation exposure in the working area of RSG-GAS reactor is safe for personnel. The dose rate distribution data have to be concerned by the worker to avoid radiation exposure during working time and make the higher safety of personnel. The radiation exposure coming out of the reactor building is very small and far bellow DLV that it is safe for the community.

\section{ACKNOWLEDGEMENT}

The author is very grateful to the head of PTKRN - BATAN, and head of BFTR which have facilitated the author in doing this work. The author also would like to thank all of the colleagues who have supported the finishing of this paper.

\section{REFERENCES}

1. Ardani, "Evaluasi dosis gamma akibat penurunan permukaan air kolam RSGGAS," Jurnal Teknologi Reaktor Nuklir, Tri Dasa Mega, vol. 9, no. 2, pp. 51-64, 2007.

2. ORNL, MCNP6.1/MCNP5/MCNPX; Monte Carlo N-Particle Transport Code System Including MCNP6.1, MCNP51.6, MCNPX-2.7 and Data Libraries. LA-CP-13-00634, Rev. 0. 2013.

3. A. Hamzah, Suwoto, A. Rohanda, H. Adrial, S. Bakhri and G.R. Sunaryo, "Neutron fluence and DPA rate analysis In pebble-bed HTR reactor vessel using MCNP," IOP Conf. Series: Journal of Physics: Conf. Series, vol. (2018) doi: 10.1088/1742-6596/962/1/012044. 
4. A. Hamzah, I. Kuntoro, "Desain konseptual perisai radiasi reaktor Rri50," Jurnal Teknologi Reaktor Nuklir Tri Dasa Mega, vol. 17, no. 2, pp 99-113, 2015.

5. G. Žerovnik, M. Podvratnik, L. Snoj, "On normalization of flux and reaction rates in MCNP criticality calculations," Annals of Nuclear Energy vol. 63, pp.126-128, 2014.

6. BAPETEN, Radiation Protection and Safety in Nuclear Power Utilization (in Indonesian), Head of BAPETEN Regulation No. 4, 2013.

7. L. Snoj, M. Ravnik, "Calculation of power density with MCNP in TRIGA reactor," International Conference, Nuclear Energy for New Europe 2006, Portorož, Slovenia, pp. 109.1-109.6.

8. J. Beric 'ic", L. Snoj, "On the calculation of angular neutron flux in MCNP", Ann. of Nuc. Energy 100, pp. 128-149, 2017.

9. BATAN, Safety Analysis Report of the Indonesian Multipurpose Reactor GASiwabessy Rev.10, 2011.

10. R.J. McConn Jr, C.J. Gesh, R.T. Pagh, R.A. Rucker, R.G. Williams III, "Compendium of Material Composition Data for Radiation Transport Modeling," PIET-43741-TM-963, PNNL-15870 Rev. 1, 2011.

11. S. El Ouahdani, H. Boukhal, L. Erradi, E. Chakir, T. El Bardouni, O. Hajjaji, Y. Boulaich, K. Benaalilou, M. Kaddour, "Monte Carlo analysis of KRITZ-2 critical benchmarks on the reactivity temperature coefficient using ENDF/BVII.1 and JENDL-4.0 nuclear data libraries," Annals of Nuclear Energy, vol. 87, pp. 107-118, 2016.

12. K.O. Kim, D. Jo, "Analysis of doppler coefficients for typical PWR $\mathrm{UO}_{2}$ and MTR $\mathrm{U}_{3} \mathrm{Si}_{2}$-Al fuels using ENDF/B-VI and VII," Annals of Nuclear Energy vol.85, pp. 1024-1028, 2015.

13. M.H. Altaf, N.H. Badrun, M.T. Chowdhury, "Computational analysis of neutronic parameters for TRIGA Mark-II research reactor using evaluated nuclear data libraries ENDF/B-VII.0 and JENDL-3.3", Annals of Nuclear Energy,vol. 80, pp. 21-27, 2015.

14. G. Ilas, I.C. Gauld, G. Radulescu, "Validation of new depletion capabilities and ENDF/B-VII data libraries in SCALE", Annals of Nuclear Energy, vol. 46, pp. 43-55, 2012.

15. P. Savva, M. Varvayanni, N. Catsaros, "Analysis of the three-dimensional VENUS-2 MOX core benchmark using the Monte Carlo code TRIPOLI-4 and the ENDF/B-VI.4, ENDF/B-VII.0 and JEFF-3.1 nuclear data sets", Nuclear Engineering and Design vol. 273, pp. 215-233, 2014.

16. Y.P. Mahlers, "VVER-1000 neutronics calculation with ENDF/B-VII data", Annals of Nuclear Energy, vol. 36, pp. 1224-1229, 2009.

17. M. Zheng, W. Tian, H. Wei, D. Zhang, Y. Wu, S. Qiu, G. Su, "Development of a MCNP-ORIGEN burn-up calculation code system and its accuracy assessment," Annals of Nuclear Energy vol. 63, pp. 491-498, 2014.

18. I. Shaaban, M. Albarhoum, "Minimizing MTR reactor uranium load with the use of MOX fuel by employing ORIGEN-S and MCNP4C codes", Annals of Nuclear Energy, vol. 83, pp. 34-40, 2015.

19. H. Benkharfia, T. Zidi, M. Belgaid, "Lumped pseudo fission products during burnup step in MCNP5-ORIGEN coupling system", Progress in Nuclear Energy, vol. 88, pp. 277-284, 2016.

20. Reactor Operation Division-Center for Multi Purpose Reactor, RSG-GAS Operation Report Core LII (in Indonesian),No.Ident.TRR.OR.19.02.41 05, Rev. 0, 2005 till Core 89, No. Ident. RSG.OR.01.04.44.16, Rev. 0, 2015. 